\title{
Potassic Fertilizer Management for Sustainable Groundnut Productivity in India: A Review
}

Bornali Borah

10.18805/ag.R-2037

\begin{abstract}
World population is exponentially rising day by day and is anticipated to reach 9.6 billion by 2050 . Agriculture in the $21^{\text {st }}$ century faces multiple challenges: it has to produce more food and fiber to feed ever growing population especially in developing countries which can be satisfied only by applying improved technologies, included rational use of fertilizers for different soil and climatic conditions. Continual nutrient mining by crop removal without adequate replenishment could result in loss of soil fertility in many developing countries. Again, human activities led to the degradation of nearly 2000 million hectares of land in the last 40 years. To meet the challenge of food security for present and future populations, to conserve natural resources and to protect the environment, it is imperative that agricultural production be conducted within an overall framework of sustainable development. Agricultural nutrients management to provide a safe food supply and secure the environment remains one of the immense challenges of the present situation. Therefore, it is very important to apply fertilizers in an efficient way to minimize loss and to improve the nutrient use efficiency for sustaining productivity as well as soil fertility.
\end{abstract}

Key words: Groundnut, Potassic fertilizers, Sources, Sustainable production, Yield.

\section{INTRODUCTION}

Plants require nutrients for the normal maintenance of their physiological and biochemical processes. The available amount of these elements is often insufficient in soils and must be supplied as fertilizers, essential inputs for the successful crop production. Potassium is a multifunctional versatile nutrient, indispensable for plants. Potassium (K) demand by crops is almost as high as that of nitrogen $(\mathrm{N})$ and plays a crucial role in many plant metabolic processes. Among the three major nutrients, potassium $(\mathrm{K})$ has a special position for its role in increasing the crop yield by adding tolerance to various biotic and abiotic stresses (Yadav et al., 2003 and Read et al., 2006). It plays a significant role in photophosphorylation, turgor maintenance, transport of photo assimilates from source tissues via phloem to sink tissues and enzyme activation in plants. Potassium has been described as the "quality element" for crop production (Usherwood 1985; Pettigrew 2008) which increases the protein content of plants, the starch content in grains and tubers, vitamin $\mathrm{C}$ and the solid soluble contents in fruits. It improves fruit color and flavor, increases the size of fruits and tubers, reduces the incidence of pests and diseases, enhances storage and shipping quality and extends shelf life. Potassium plays major role in regulating water relations for plants making them to survive under drought stress. Insufficient $\mathrm{K}$ application results in soil $\mathrm{K}$ mining, deficiency symptoms in crops and decreased crop yields and quality. Crop $\mathrm{K}$ demands vary with crop types, growth patterns, nutrient needs at different physiological stages and productivity.

Groundnut (Arachis hypogaea L.) is considered as the most important oilseed crop among the nine major oilseed crops grown in India, as it contains $43-55 \%$ oil and $25-28 \%$
Department of Soil Science, M.S. Swaminathan School of Agriculture, Centurion University of Technology and Management, Paralakhemundi-761 211, Odisha, India.

Corresponding Author: Bornali Borah, Department of Soil Science, M.S. Swaminathan School of Agriculture, Centurion University of Technology and Management, Paralakhemundi-761 211, Odisha, India. Email: bornaliborah1993@gmail.com

How to cite this article: Borah, B. (2021). Potassic Fertilizer Management for Sustainable Groundnut Productivity in India: A Review. Agricultural Reviews. 42(4): 398-405. DOI: 10.18805/ ag. R-2037.

Submitted: 12-06-2020 Accepted: 21-06-2021 Online: 31-07-2021

protein. However, the productivity of this crop is low in India due to rainfed cultivation ( $85 \%)$, monoculture $(60 \%)$ and cultivation on marginal land (Jat et al., 2011). In India, Gujarat was ranked first in area under cultivation (1.84 million ha), production (4.92 million $\mathrm{Mg}$ ) and productivity $\left(2,670 \mathrm{~kg} \mathrm{ha}^{-1}\right)$ in 2013-14. According to Statista Research Department data published on October 16, 2020 India produced more than six million metric tons of groundnut at the end of fiscal year 2019. However, there was a decrease in production from the previous fiscal year.

\section{Forms of potassium in soil}

Potassium is present in soil as four distinct pools according to the availability of the potassium for uptake by plant. The average $\mathrm{K}$ contain in soil is $0.04-3 \%$ with the general ranges between 10 and $20 \mathrm{~g}$ per $\mathrm{kg}$ of total $\mathrm{K}$ content in the upper $0.2 \mathrm{~m}$ of most agricultural soil. Most of the soil $\mathrm{K}(90-98 \%)$ is associated with the crystal lattice structure of minerals and thus cannot be taken up by plants directly. 
The availability of $\mathrm{K}$ greatly influences by soil types and also affected by physico-chemical properties of the soil. $\mathrm{K}$ in soil is often classified into four groups on the basis of its availability to plants: water-soluble, exchangeable, nonexchangeable and structural or mineral forms. Soil $\mathrm{K}$ availability, in the short and long term is an outcome of complex dynamics between these four distinct $\mathrm{K}$ phases. Among these forms, water-soluble $\mathrm{K}$ is directly available for plants and soil microbes and potentially subjected to leaching loss. The exchangeable potassium is bound electro-statically on outer-surface of clay minerals and subjected to exchange with other cations. Both these fractions' constituents the easily available $\mathrm{K}$ pool for crops. However, the size of both pools is very small which make up only about $0.1-0.2 \%$ and $1-2 \%$ of the total $\mathrm{K}$ in soil, respectively. Non-exchangeable and structural/mineral forms are considered to be slowly or non-available $\mathrm{K}$ forms for plants. However, in long term $\mathrm{K}$ supply to plants, these pools may contribute significantly. Potassium is the element absorbed by plant in huge quantity than other essential elements except nitrogen. Potassium constitutes about $2.1 \%$ of the earth's crust and listed as the seventh most abundant element. Therefore, there is a large reserve of potassium available in soil but in structural form which is unavailable to plants. Most of the agricultural area of the world is reported to be deficient in $\mathrm{K}$ availability mainly due to its slow release as compare to requirement of the crop. Quantity of available and unavailable potassium in the soil varies from soil to soil and dynamic equilibrium between the different pools of potassium in soil. Thus, fixation and release of potassium from mineral soil is affected by a number of soils physicochemical properties as well as plant interactions and soil microbial activity.

The records of recent studies conducted in intensively cultivated areas of India showed that imbalance use of $\mathrm{N}$, optimal to suboptimal use of $\mathrm{P}$ and complete negligence of $\mathrm{K}$ application by the farmers are the major causes of depletion of soil $\mathrm{K}$ fertility with high nutrient demand and excessive extraction of $\mathrm{K}$ in intensive production systems of Asia (Dwivedi et al., 2001; Singh et al., 2015; Timsina et al., 2013). Such depletion was further aggravated by the practice of removing crop residues from the field for other uses, mainly as animal feed. This has resulted in widespread $\mathrm{K}$ deficiency in many soils, including the fine-textured soils that initially had high soil $\mathrm{K}$ contents. Many other evidences from long-term experiments in different cropping systems in India and elsewhere showed significant yield responses to applied $\mathrm{K}$ and negative $\mathrm{K}$ balances where $\mathrm{K}$ application is either excluded or applied insufficiently (Dwivedi et al., 2017). The content of $\mathrm{K}$ in crops depends on soil type, crop as well as fertilizer input; however, concentrations in the range of $0.4-4.3 \%$ have been reported (Askegaard et al. 2004). As India falls under monsoon climates, heavy rainfall often causes $\mathrm{K}$ loss due to leaching from the soluble and exchangeable phases. On the other hand, certain clay minerals tend to exhibit strong $\mathrm{K}$ fixation (Zörb et al., 2014). Therefore, appropriate fertilizer recommendations must be based on recent soil testing. Moreover, apart from total crop $\mathrm{K}$ requirement per season, the appropriate timing of application must be considered for better $\mathrm{K}$ use efficiency.

\section{Visual symptoms of potassium deficiency}

The deficiency of $\mathrm{K}$ can impair several processes (Marschner 2002) viz; inhibition of enzymatic activities, increase susceptibility of plants to fungal attack, impair stomatal activity that results in poor photosynthesis and water control, imbalances gas exchange and making plants more vulnerable to biotic as well as abiotic stresses. Potassium also regulates cell turgidity and rigidity by maintaining the osmotic potential. The visual symptoms of potassium deficiency generally occur first on older tissue because $K$ is mobile in the plant. Therefore, when insufficient uptake of $\mathrm{K}$ from the soil occurs it can be remobilized from older tissue to recently matured younger tissue. Potassium deficiency may first appear as deep green plants with shorter and fewer internodes and smaller leaves, followed by the rapid development of necrotic spots along the margins and across leaf blades of recently matured leaves. The necrotic lesions may begin without prior formation of chlorotic lesions. However, in some cases, chlorosis develops in the tissue surrounding necrotic spots as the necrosis enlarges in advanced stages, followed by chlorosis on recently matured and maturing leaves.

\section{Importance of potassium in groundnut production}

Potassium is an essential macro-element for all living organisms which are required in huge amount for normal plant growth and development. Groundnut crop responds well for potassium $(\mathrm{K})$ application and concentration of $\mathrm{K}$ at all stages in groundnut crop increases due to its supply. The high $\mathrm{K}$ concentration in initial stages and declining in the later stage indicated greater absorption of $K$ in early stages by groundnut crop (Madkour et al., 1992). The potassium application improves the kernel size, test weight and shelling percentage of groundnut. Potassium plays significant role in maintaining balance in enzymatic, stomatal activity (water use), transport of sugars, water and nutrient and synthesis of protein, photosynthesis and starch thus $\mathrm{K}$ application increases growth and yield attributes in groundnut (Krauss and Jiyun 2000; Rathore et al., 2014). Potassium governs plant turgor and is involved in stomatal conductance (Marschner, 2012), It also contributes to the survival of plants exposed to various biotic and abiotic stresses, such as diseases, pests, drought, salinity, cold, frost and waterlogging (Wang et al., 2013). Enhanced nitrogen metabolism results due to potassium application. The application of $\mathrm{K}$ along with existing recommendation of $\mathrm{N}$ and $\mathrm{P}$ leads to increase in the groundnut production. Potassium deficiency unlike nitrogen deficiency restricts fruit production to a larger extent than vegetative growth (Kirby et al., 1985, Pettigrew and Meredith 1997). 


\section{Potassium requirements by groundnut crop}

Potassium is the second most absorbed nutrient by the groundnut crop (Tasso Júnior et al., 2004), which having beneficial effect on nitrogen fixation and translocation of photosynthates from the leaves to the root nodules (Savani et al., 1995). In soils with low potassium contents, groundnut responds expressively to application of $\mathrm{K}$ fertilizer. The optimization of mineral nutrition is key to successful groundnut production, as the nutrient demand of this crop is very high. As compared to traditional varieties, modern high-yielding groundnut varieties remove more nutrients from the soil. The crop can remove 100 to $200 \mathrm{~kg} \mathrm{~K}_{2} \mathrm{O}$ ha $^{-1}$ during a growing season. This is usually far in excess of that released from slowly exchangeable sources in soils low in available K. Singh (2007) reported that the main shoot height, number of branches plant ${ }^{-1}$, kernel pod ${ }^{-1}$ increased with application of $60 \mathrm{~kg} \mathrm{~K}_{2} \mathrm{O}+45 \mathrm{~kg} \mathrm{~S}+60 \mathrm{~kg} \mathrm{Ca} \mathrm{ha}^{-1}$. The export-oriented groundnut produced significantly a greater number of filled pods plant ${ }^{-1}$ with higher shelling percentage and test weight by the application of $75 \mathrm{~K}_{2} \mathrm{O} \mathrm{kg} \mathrm{ha}{ }^{-1}$ compared to the high dose of $100 \mathrm{~K}_{2} \mathrm{O} \mathrm{kg} \mathrm{ha}{ }^{-1}$. Eventually, the pod and haulm yield were also significantly more at $75 \mathrm{~K}_{2} \mathrm{O} \mathrm{kg} \mathrm{ha-1}$ than the high level of $\mathrm{K}_{2} \mathrm{O}$ (Reddy et al. 2011). Salve and Gunjal (2011) reported that application of 30 and $45 \mathrm{~kg} \mathrm{~K}_{2} \mathrm{O}$ ha $^{-1}$ were found to be at par with each other but significantly increased number of branches plant ${ }^{-1}$, dry matter production plant $^{-1}$, root nodules and their weight plant ${ }^{-1}$ at flowering and pod development stages, protein and oil content in kernel and their yields as compared to application of $15 \mathrm{~kg} \mathrm{~K}_{2} \mathrm{O} \mathrm{ha-1}$. Rathore et al. (2014) reported that among Schoenite levels, $60 \mathrm{~kg} \mathrm{ha}^{-1}$ results in the maximum increase in number of branches plant ${ }^{-1}$ at 90 DAS, number of plants $\mathrm{m}^{-2}$ and number of pods plant ${ }^{-1}$ at harvest. The highest total number of pegs plant $^{-1}, 1000$ seed weight and maximum shelling percentage was recorded with $60 \mathrm{~kg} \mathrm{~K}_{2} \mathrm{O} \mathrm{ha}^{-1}$ through Schoenite as compared to different levels of sulphate of potash. Srinivasarao et al., (2010) reported that, the application of graded levels of $\mathrm{K}$ significantly increased the $\mathrm{K}$ content of various parts of the groundnut and leaf and shells $\mathrm{K}$ content was higher compared to that of the pod (Fig 2).

Many studies have been carried out on groundnut fertilization in India, emphasizing the importance of potassium nutrition for proper crop stand of groundnut. From a study, Mandal et al. (2002) reported that on average,

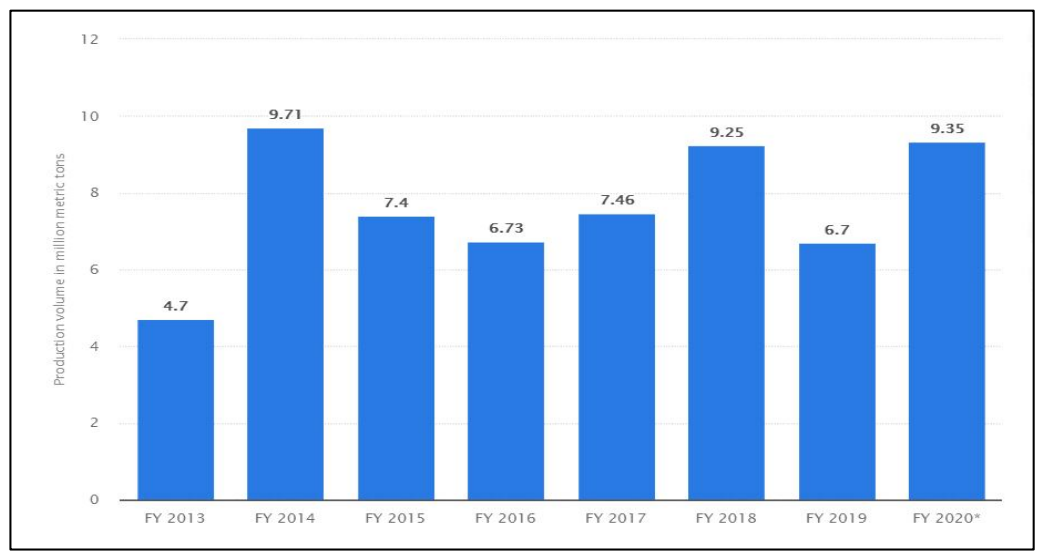

Fig 1: Production status of groundnut across India from financial year 2013 to 2019, with estimates until 2020 (in million metric tons). Source: Statista Research Department (2020).

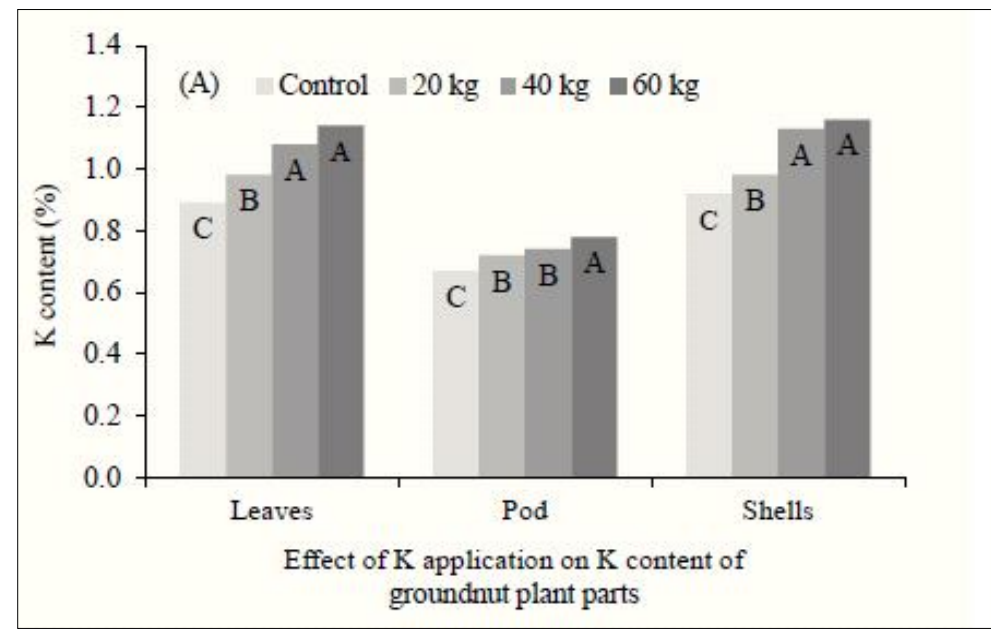

Fig 2: Effect of different levels of $\mathrm{K}$ on groundnut plant parts (Srinivasarao et al., 2010). 
groundnut requires yearly $160-180 \mathrm{~kg}$ nitrogen $(\mathrm{N}), 20-25$ $\mathrm{kg}$ of phosphorus $(\mathrm{P})$ and $80-100 \mathrm{~kg}$ of $\mathrm{K}$ to produce 2.0 to $2.5 \mathrm{Mg} \mathrm{ha}^{-1}$ of economic yield. The studies focused on the appropriate time of fertilizer application (Ghosh et al., 2003; Chitdeshwari et al., 2007) demonstrated that during the intensive growth period of groundnut from 30 to 70 days after sowing (DAS), including initiation of the reproductive phase, namely bloom, pegging and pod setting, nutrient requirements uprises. To ensure sufficient nutrient availability during this critical period, application of fertilizer at the required quantity proved beneficial. Several studies focused on split K application (Chinnasamy, 1993; Ponnuswamy et al., 1996), all of which reported significantly higher yields as compared to a single, basal application. Therefore, split $\mathrm{K}$ application should be adopted and quantitatively adjusted according to local conditions.

\section{Major sources of potassium for groundnut cultivation}

Potassium fertilizers are one commodity for which country depends solely on import at the expense of heavy foreign exchange. The country imported 3380 thousand tonnes of $k$ during 2008-2009. Indigenously the process of production of Sulphate of potash $\left(\mathrm{K}_{2} \mathrm{SO}_{4}\right)$ and Schoenite $\left(\mathrm{K}_{2} \mathrm{SO}_{4} \cdot \mathrm{MgSO}_{4}\right)$ from sea bittern has been developed by Central Salt and Marine Chemical Research Institute, Bhavnagar, Gujarat (Rathore et al. 2014). Among common potassic fertilizers, Sulphate of potash, is mostly favored by the majority of growers since it's low salt index, non-hygroscopic and chlorine free K-fertilizer in comparison with muriate of potash, which is a cheaper source of K-fertilizer but requires specific soil physical properties and some arrangements with irrigation to avoid toxic effect of chlorine. Another important source of potassium as plant nutrient is bagasse ash, which is a type of organic waste obtained from sugar industry during the process of sugar production. Research considers bagasse ash as a good source of micronutrients like $\mathrm{Fe}, \mathrm{Mn}, \mathrm{Zn}$ and $\mathrm{Cu}$ (Anguissola et al., 1999). It can also be used as soil additives in agriculture farming having its capacity to supply the plants with small amount of nutrients (Carlson and Adriano 1993). Bagasse ash contains no N, but there are commonly high concentration of $\mathrm{K}$ and $\mathrm{P}$. Therefore, it's use in agriculture for crop production will be proved more beneficial.
India is the prominent producer and consumer of sugar in the world. Among the several industries sugar industry is the most important which produces annually $7.4 \mathrm{Mt}$ bagasse ash (FAl 2011) which can be use as organic amendment which having favorable effect on soil water holding capacity and aeration (Singh et al; 2002). Thus, application of bagasse ash for crop production is a useful practice for reducing the cost of fertilizer application and safe disposal of the waste.

Sulphatic $\mathrm{K}$ fertilizers are to be preferred for seedbed application since they ensure a supply of available $S$ for the first 20-30 days of crop development. Schilung and Hirsch (1974) obtained good responses to $\mathrm{K}$ but no difference in the effects of $\mathrm{KCl}$ and $\mathrm{K}_{2} \mathrm{SO}_{4}$. In further investigations they found that $\mathrm{Cl}$ content was positively correlated with yield of pods while there was no correlation of yield with the contents of other elements but, though the $\mathrm{K}$ and $\mathrm{Cl}$ contents of the leaves were negatively related, they still found no difference in the effects of $\mathrm{KCl}_{\text {and }} \mathrm{K}_{2} \mathrm{SO}_{4}$. Rathore et al. (2014) reported that maximum dry pod yield, harvest index and oil yield was recorded in $60 \mathrm{~kg} \mathrm{ha}^{-1}$ potash through schoenite during both experimental year (2006-08) and was a sharp increase in dry pod yield from $40 \mathrm{~kg}$ potash $\mathrm{ha}^{-1}$ through schoenite + sulphate of potash and $40 \mathrm{~kg}$ potash ha-1 through sulphate of potash to $60 \mathrm{~kg} \mathrm{~K}_{2} \mathrm{O}$ ha $^{-1}$ through only schoenite. The names and chemical formulas along with $\mathrm{K}$ concentrations of some common K-bearing minerals used in production of potash fertilizers are listed in the (Table 1). However, as sufficient potassic mineral deposits are not available in India for producing potassic fertilizers; our country imports 100\% of its potassic requirement from countries like Canada, Germany, Belarus, Jordan, Israel and UK (Kinekar, 2011) which was 1.926 million tonnes for 2013-14. In 2019, among the top exporters of Potassic Fertilizers Canada was in the first rank followed by Belarus and Russia (Fig 3).

For the organic production system, manures can server as an excellent organic source of $\mathrm{K}$ due to significant amount of $\mathrm{K}_{2} \mathrm{O}$ content in majority of animal manures (Table 2). When manure is applied at a rate to meet the $\mathrm{N}$ demand of a crop, the $P$ and $K$ will likely be in excess of the crop requirement. Essentially all of the $K$ is available for plant growth the year manure is applied. Nutrient content of manure varies widely,

Table 1: Names with chemical formulas and $\mathrm{K}$ concentrations of some common K-bearing minerals used in production of potash fertilizers.

\begin{tabular}{|c|c|c|c|}
\hline Mineral & Chemical name & Chemical formula & Weight $\% \mathrm{~K}_{2} \mathrm{O}$ \\
\hline Carnallite & Potassium magnesium chloride & $\mathrm{KCl} \cdot \mathrm{MgCL}_{2} \cdot 6 \mathrm{H}_{2} \mathrm{O}$ & 17 \\
\hline Carnallitite (ore) & Mixture of carnallite, halite and others & $\begin{array}{l}\mathrm{KCl} \cdot \mathrm{MgCL}_{2} \cdot 6 \mathrm{H}_{2} \mathrm{O}, \mathrm{NaCl} \\
\mathrm{MgSO}_{4} \cdot \mathrm{H}_{2} \mathrm{O}, \mathrm{CaSO}_{4}\end{array}$ & Variable \\
\hline Kainite & Potassium magnesium sulfate chloride & $\mathrm{KCl} \cdot \mathrm{MgSO}_{4} \cdot 3 \mathrm{H}_{2} \mathrm{O}$ & 19 \\
\hline Langbeinite & Potassium magnesium sulfate & $\mathrm{K}_{2} \mathrm{SO}_{4} \cdot 2 \mathrm{MgSO}_{4}$ & 23 \\
\hline Niter & Potassium nitrate & $\mathrm{KNO}_{3}$ & 46 \\
\hline Schoenite & Potassium magnesium sulfate & $\mathrm{K}_{2} \mathrm{SO}_{4} \cdot \mathrm{MgSO}_{4} \cdot 2 \mathrm{CaSO}_{4} \cdot 2 \mathrm{H}_{2} \mathrm{O}$ & 23 \\
\hline Sylvinite (ore) & Mixture of sylvite and halite & $\mathrm{KCl}, \mathrm{NaCl}$ & Variable \\
\hline Sylvite & Potassium chloride & $\mathrm{KCl}$ & 63 \\
\hline
\end{tabular}


according to the types and stage of animal. Therefore, it is advisable to have a manure and soil sample tested before application of manure to a field in order to supply specific nutrient required for crop growth. In the mixed livestock/crop systems, the nutrition of the animals generally takes first priority and the residual manure is returned to surrounding cropland. Large losses of $\mathrm{K}$ often occur on these farms during manure storage and composting as the excreted $\mathrm{K}$ is mostly expelled as urine. If not properly handle, this fraction may not effectively recover in confined animal operations and most of the $\mathrm{K}$ will not be returned to the field along with the solid portion of the manure. The nutrient value of $\mathrm{K}$ in animal manures is generally equivalent to soluble $\mathrm{K}$ fertilizers. Since $\mathrm{K}$ is not a structural component of plant or animal cells and remains soluble in animal manure and urine, there is no true "organic" $\mathrm{K}$. However, the concentrations of nutrients in manure are generally far below than inorganic fertilizers that it is uneconomical to transport manure to a long distance. Therefore, manure use is primarily local, often restricted to a single farm or nearby farms (Mikkelsen 2000). Furthermore, animal manure provides additional benefits by aid in building stable soil structure and remediating soil (Mikha et al., 2017).

\section{Foliar fertilization of potassium in groundnut}

Foliar nutrition is an effective method for correcting deficiencies and overcoming the soil's inability to transfer nutrients to the plant. Most crops have a relatively high demand for $\mathrm{K}$ throughout the growing season. In the case where $\mathrm{K}$ uptake is insufficient, spraying an aqueous $\mathrm{K}$ containing solution directly onto the plant foliage often overcomes this deficiency (Mikkelsen 2017). Applications of K-containing sprays directly onto the foliage of annual and perennial crops are common. Availability of essential

Table 2: Dry matter and $\mathrm{K}_{2} \mathrm{O}$ content (approximate) of selected animal manures (IPNI 2012).

\begin{tabular}{|c|c|c|c|}
\hline Livestock type & Waste handling system & Dry matter\% & $\mathrm{K}_{2} \mathrm{O}$ content $\mathrm{kg} \mathrm{t}^{-1}$ \\
\hline \multicolumn{4}{|c|}{ Solid handling systems } \\
\hline \multirow[t]{2}{*}{ Beef cattle } & Without bedding & 15 & 5 \\
\hline & With bedding & 50 & 13 \\
\hline \multirow[t]{2}{*}{ Dairy cattle } & Without bedding & 18 & 5 \\
\hline & With bedding & 21 & 5 \\
\hline \multirow[t]{2}{*}{ Swine } & Without bedding & 18 & 4 \\
\hline & With bedding & 18 & 3.5 \\
\hline \multirow[t]{4}{*}{ Poultry } & Without litter & 45 & 5 \\
\hline & With litter & 75 & 17 \\
\hline & Deep pit (compost) & 76 & 22.5 \\
\hline & \multicolumn{2}{|c|}{ Liquid handling systems } & \\
\hline \multirow[t]{2}{*}{ Beef cattle } & Liquid pit & 11 & 17 \\
\hline & Oxidation ditch & 3 & 14.5 \\
\hline \multirow[t]{2}{*}{ Dairy cattle } & Lagoon & 1 & 2.5 \\
\hline & Liquid pit & 8 & 14.5 \\
\hline \multirow[t]{3}{*}{ Swine } & Liquid pit & 4 & 9.5 \\
\hline & Oxidation & 2.5 & 9.5 \\
\hline & Ditch lagoon & 1 & 0.2 \\
\hline \multirow[t]{2}{*}{ Poultry } & Lagoon & 1 & 2.5 \\
\hline & Liquid pit & 3 & 48 \\
\hline
\end{tabular}

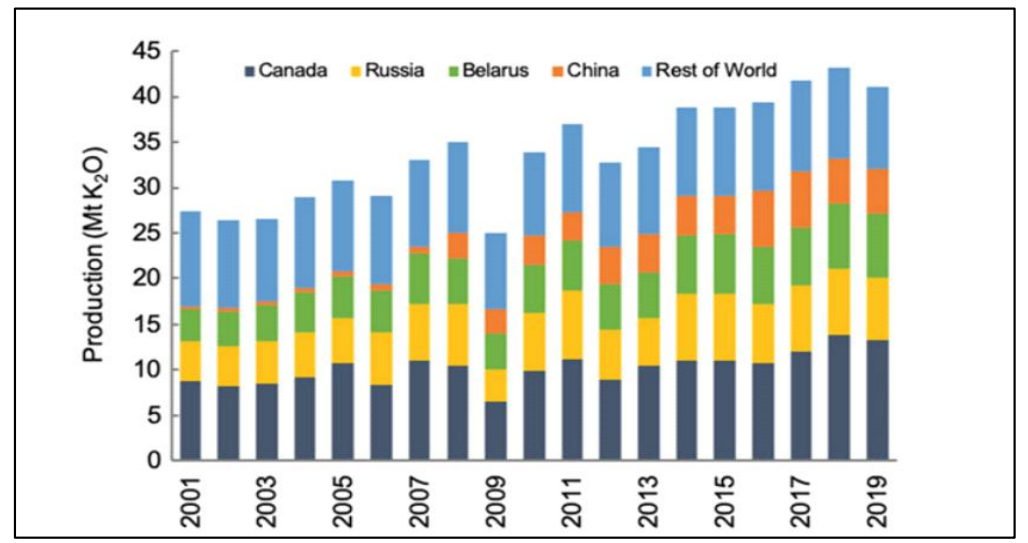

Fig 3: Global potash mine production between 2000 and 2019. (Jasinksi 2020). 
nutrients and trace minerals from the soil may be limited at times by root distribution, soil temperature, soil moisture, nutrient imbalances and other factors. Foliar nutrition can maintain a nutrient balance within the plant, which may not occur strictly with soil uptake (Meena et al., 2007). Foliar nutrition is $8-10$ times more effective than soil application which stimulates an increase in chlorophyll production, cellular activity and respiration. It also triggers a plant response to increased water and nutrient uptake from the soil (Veramani et al., 2012). Groundnut can resist water stress conditions but shows adverse effects of drought on the pod yield and seed quality (Stansell et al., 1976; Nageswara Rao et al., 1989). The chemical composition of the groundnut seeds affected by drought, which is limited in the mid-season drought but significant in end-season drought (Conkerton et al., 1989; Musingo et al., 1989; Dwivedi et al., 1996). Umar (2006) reported that groundnut may be cultivated under drought conditions along with potassium fertilization in order to minimize the adverse effects of water stress. Furthermore, foliar fertilization has advantages of low application rates, uniform distribution of fertilizer materials and quick response to nutrients. To counteract cyclic droughts, foliar fertilization with $\mathrm{K}$ for groundnut in Gujarat, India is considered beneficial (Glokiya and Patel, 1988). Umar et al. (1999) reported that the best results of groundnut plants were achieved with foliar application of $1 \% \mathrm{KCl}$. Moreover, many researches showed that the response of quality parameters like protein and oil contents of seed was more consistent with foliar applied $\mathrm{K}_{2} \mathrm{SO}_{4}$ than soil application. However, repeated applications of foliar $\mathrm{K}$ solutions with a high concentration of fertilizer salt leads to leaf damage ("salt burn"). Therefore, before beginning a foliar fertilization program it is required to identify the appropriate 4R-based practices (Right source, right rate, right time and right place) suited to a specific crop and agroenvironment. There are several excellent $\mathrm{K}$ fertilizer sources that are used for foliar spraying and the most common of these are $\mathrm{KH}_{2} \mathrm{PO}_{4}, \mathrm{~K}_{2} \mathrm{SO}_{4}, \mathrm{KNO}_{3}$ and some organic-based formulations.

\section{How is potassium released from different fertilizer?}

The plant roots can take potassium only from soil solution so it must be in the soil solution to uptake by roots in the transpiration stream. Most of the inorganic $\mathrm{K}$ fertilizers are water soluble therefore, after its application fertilizer $\mathrm{K}$ does not usually persist in solid granules in the soil for long. As long as the soil moisture content is greater than that at permanent wilting point, there will be a rapid increase in soil solution $\mathrm{K}$ in response to fertilizer application.

\section{CONCLUSION}

Groundnut (Arachis hypogaea L.) is a unique and important legume-oilseed crop of Indian agricultural system, contributing about 40 per cent of area and 30 per cent of the production of oilseed crops in India. As regards the nutritional value of groundnut, its seed contains about 40-50 per cent oil, 2030 per cent protein and $10-20$ per cent carbohydrates
(Okello et al., 2010). At present, India ranks $2^{\text {nd }}$ after China with 33 per cent of world's total production, but the productivity is far below than the countries like China, Israel and USA. The reason might be, this crop is grown traditionally in dry land regions of India those characterized by erratic rainfall, poor soil fertility and low input levels. It is widely cultivated by farmers of the Sub-montane Zone of India with recommended dose of fertilizer 25:50 (N: $\mathrm{P}_{2} \mathrm{O}_{5}$ $\left.\mathrm{kg} \mathrm{ha}^{-1}\right)$. The optimization of the mineral nutrition has key role in optimization the production of groundnut because it has very high nutrient requirement. On contrary groundnut farmers use very less fertilizer resulting in severe mineral nutrient deficiencies which is one of the major factors responsible for low yield in groundnut (Veermani et al. 2012). There are various imported and indigenously produced and organic sources of potassium available, relative efficiency in crops like groundnut need to be evaluated. Hence a proper understanding of management practices for potassic fertilizers are necessary for enhancing and sustaining productivity of groundnut which in turn helps our country to avoid shortage of edible oils and large-scale imports at the expense of huge foreign exchange.

\section{REFERENCES}

Anguissola, S., Silva, Botteschi, G. (1999). Effect of fly ash on the availability of $\mathrm{Zn}, \mathrm{Cu}, \mathrm{Ni}$ and $\mathrm{Cd}$ to chi-cory. Agricultural Ecosystem and Environment. 72: 159-163.

Askegaard, M., Eriksen, J. and Johnston, A.E. (2004). Sustainable Management of Potassium. In: Managing Soil Quality: Challenges in Modern Agriculture. [Schjorring, P., Elmholt, S., Christensen, B.T. (eds)]. CABI, Wallingford. pp. 85-102.

Carlson, C.L. and Adriano, D.C. (1993). Environmental impacts of coal combustion on residues. Journal of Environmental Quality. 22: 227-47.

Chinnasamy, C. (1993). Studies on the effect of split application of nitrogen and potassium on the yield performance of irrigated groundnut (VRI 2) under various methods and times of application. M.Sc. (Ag.). Thesis, Tamil Nadu Agricultural University, Coimbatore.

Chitdeshwari, T., Selvaraj, P.K. and Shanmugam, P.M. (2007). Influence of levels and split application of fertilizers on the yield and nutrient uptake by groundnut. Agricultural Science Digest. 27(2): 91-94.

Conkerton, E.J., Ross, L.F., Daigle, D.J., Kvien, C.S. and Mc-Combs, C. (1989). The effect of drought stress on peanut seed composition. II. Oil, protein and minerals. Oleagineux. 44: 593-599.

Dwivedi, S.L., Nigam, S.N., Nageswara Rao, R.C., Singh, U. and Rao, K.V.S. (1996). Effect of drought on oil, fatty acids and protein contents of groundnut (Arachis hypogaea L.) seeds. Field Crops Research. 48: 125-133.

Dwivedi, B.S., Shukla, A.K., Singh, V.K. and Yadav, R.L. (2001). Results of Participatory Diagnosis of Constraints and Opportunities-based Trials from the State of Uttar Pradesh. In: Development of Farmers' Resource-based Integrated Plant Nutrient Supply Systems: Experience of a FAOICARIFFCO Collaborative Project and AICRP on Soil Test Crop Response Correlation. [Rao, S., Srivastava, S. (eds)]. Indian Institute of Soil Science, Bhopal, India. pp 50-75. 
Dwivedi, B.S., Singh, V.K., Shekhawat, K., Meena, M.C. and Dey, A. (2017). Enhancing use efficiency of phosphorus and potassium under different cropping systems of India. Indian Journal of Fertilizers. 13(8): 2041.

FAI (2011). Fertilizer Statistics 2010-11, 56 th edn. Fertilizer Association of India, New Delhi.

Ghosh, P.K., Dayal, D., Mandal, K.G., Wanjari, R.H. and Hati, K.M. (2003). Optimization of fertilizer schedules in fallow and groundnut-based cropping systems and an assessment of system sustainability. Field Crops Research. 80(2): 83-98.

Glokiya, B.A. and Patel, M.S. (1988). Role of potassium in counteracting the effect of cyclic drought on groundnut. Journal of Potassium Research. 4: 163-167.

IPNI (2012). 4R Plant Nutrition Manual: A Manual for Improving the Management of Plant Nutrition. Metric Version. In: [Bruulsema T.W., Fixen, P.E., Sulewski, G.D. (eds)] International Plant Nutrition Institute, Norcross.

Jasinski, S.M. (2020). Mineral commodity summaries-Potash 2020 : United States Geological Survey. p. 126-127.

Jat, R.S., Meena, H.N., Singh, A.L., Surya, J.N. and Misra, J.B. (2011). Weed management in groundnut (Arachis hypogaea L.) in India - A review. Agricultural Reviews. 32(3). 155-171.

Kinekar, B. (2011). Potassium fertilizer situation in India: Current use and perspectives. Karnataka Journal of Agricultural Science. 24: 1-6.

Krauss, A. and Jiyun, J. (2000). Strategies for Improving Balanced Fertilization. IFA Production and International Trade Conference, 17-19 October, Shanghai, China.

Madkour, M.A., Salwa, I., El-Mohandas, El-Wakil, A.M. (1992). Effect of row spacing, phosphorus, potassium and boron application on some groundnut cultivars. Egyptian Journal of Agronomy. 17(1-2): 127-140.

Mandal, K.G., Ghosh, P.K., Wanjari, R.H., Hati, K.M., Bandyopadhyay, K.K. and Misra, A.K. (2002). Practical implication of nutrient $\times$ nutrient interaction to boost oilseeds Productivity in India. Fertilizer Research. 47(7): 13- 18 and 21-26.

Marschner, H. (2002). Mineral Nutrition of Higher Plants, $2^{\text {nd }}$ edn. Academic Press, New York.

Marschner, P. (2012). Marschner's Mineral Nutrition of Higher Plants, $3^{\text {rd }}$ ed. Academic Press: London, UK, 2012. p. 178-189.

Meena, S., Malarkodi, M. and Senthilvalavan, P. (2007). Secondary and micronutrients for groundnut $-A$ review. Agricultural Review. 28(4): 295-300.

Mikha, M.M., Benjamin, J.G., Vigil, M.F. and Poss, D.J. (2017). Manure use and tillage use in remediation of eroded land and impacts on soil chemical properties. PLoS One. 12(4): e0175533. doi: 10.1371/journal.pone.0175533.

Mikkelsen, R.L. (2000). Beneficial Use of Swine By-products: Opportunities for the Future. In: Beneficial Uses of Agricultural, Industrial, and Municipal by-products. [Powers, J. et al. (eds)] Soil Science Society of America. Madison. pp 451-480.

Mikkelsen, R.L. (2017). The importance of potassium management for horticultural crops. Indian Journal of Fertilizer. 13(11): 82-86.
Musingo, M.N., Basha, S.M., Sanders, T.H., Cole, R.J. and Blankenship, P.D. (1989). Effect of drought and temperature stress on peanut (Arachis hypogaea L.) seed composition. Journal of Plant Physiology. 134: 710-715.

Nageswara Rao, R.C., Williams, J.H. and Singh, M. (1989). Genotypic sensitivity to drought and yield potential of peanut. Agronomy Journal. 81: 887-893.

Okello, D.K., Biruma, M. and Deom, C.M. (2010). Overview of groundnut research in Uganda: Past, present and future. African Journal of Biotechnology. 9: 6448-59.

Pettigrew, W.T. (2008). Potassium influences on yield and quality production for maize, wheat, soybean and cotton. Physiologia Plantarum. 133: 670-68.

Pettigrew, W.T. and Meredith, W.R. Jr. (1997). Dry matter production, nutrient uptake, and growth of cotton as affected by potassium fertilization. Journal of Plant Nutrition. 20: 531-548.

Ponnuswamy, K., Balakrishnan, V.K., and Santhi, P. (1996). Exploiting the production potential of groundnut by improved nutrient management in the lower Bhavani Project Area, Tamil Nadu, India. International Arachis Newsletter. 16: 50-52.

Rathore, S.S. and Chaudhary, D.R., Vaisya L.K., Shekhawat Kapila and Bhatt, B.P. (2014). Schoenite and Potasium Sulphate: Indigenous Potassic Fertilizer for Rainfed Groundnut (Arachis hypogea L.). Indian Journal traditional Knowledge. 13(1): 222-226.

Read, J.J., Raja Reddy, K. and Jenkins, J.J. (2006). Yield and fiber quality of upland cotton as influenced by nitrogen and potassium nutrition. European Journal of Agronomy. 24: 282-290.

Reddy, S.T., Reddy, D.S. and Reddy, G.P. (2011). Fertilize management for maximizing productivity and profitability of export-oriented groundnut (Arachis hypogaea L.) Journal of Research ANGRAU. 39(4): 83-85.

Salve, Y.V. and Gunjal, B.S. (2011). Effect of different levels of phosphorus and potassium on summer groundnut (Arachis hypogaea L.). International Journal of Agricultural Science. 7(2): 352-355.

Savani, V.N., Vaioshnav, M.R., Vaishnav P.R.; Darji, V.B. (1995). Statistical estimation of relative changes in $P$ content with different levels of applied phosphorus in groundnut. Journal of Gujarat Agricultural University. 21: 119-123.

Schilling, R. and Hirsch, P.J. (1974). Chlorine nutrition of peanuts in Senegal. Oleagineu. 29: 8 5-90.

Singh, C.B., Oswal, M.C. and Grewal, K.S. (2002). Impact of fly ash application on consumptive and water use efficiency in wheat (Triticum aestivum) under different soils. Indian Journal of Agricultural Science. 72: 396-9.

Singh, R.A. (2007). Effect of variable doses of potassium, sulphur and calcium on pod yield of short duration summer groundnut (Arachis hypogea L.). International Journal of Agricultural Science. 3(1): 196-198.

Singh, V.K., Shukla, A.K., Dwivedi, B.S., Singh, M.P., Majumdar, K., Kumar, V., Mishra, R., Rani, M. and Singh, S.K. (2015). Site -specific nutrient management under rice-based cropping systems in Indo-Gangetic Plains: Yield, profit and apparent nutrient balance. Agricultural Research. 144-52. 
Srinivasarao, Ch., Venkateswarlu, B., Dixit, S. and Singh, A.K. (2010). Potassium Deficiency in Soils and Crops: Emerging Soil Fertility Constraint in Dryland Agriculture. Central Research Institute for Dryland Agriculture, Hyderabad, India. p. 34.

Stansell, J.R., Shepard, J.L., Pallas, Jr. J.E., Bruce, R.R., Minton, N.A., Bell, D.K. and Morgan, L.W. (1976). Peanut responses to soil water variables in the Southeast. Peanut Science. 3: 44-48.

Tasso, J.R., L.C., Marques, M.O., Nogueira, G.A.L. (2004). A cultura do amendoim, Firsted., Jaboticabal: UNESP, 218 p.

Timsina, J., Singh, V.K. and Majumdar, K. (2013). Potassium management in rice-maize systems in South Asia. Journal of Plant Nutrition and Soil Science. 176(3): 317-330.

Umar, S. (2006). Alleviating adverse effects of water stress on yield of sorghum, mustard and groundnut by potassium application. Pakistan Journal of Botany. 38(5): 196-198.

Umar, S., Bansal, S.K., Patricia, I. and Magen, H. (1999). Effect of foliar fertilization of potassium on yield, quality and nutrient uptake of groundnut. Journal of Plant Nutrition. 22(11): 1785-1795.
Usherwood, N.R. (1985). The Role of Potassium in Crop. 7 Edition. quality. In: Potassium in Agriculture, [R.D. Munson, (Ed.)]. ASA-CSSA-SSSA, Madison, W.I. pp. 489-513.

Veeramani, P., Subrahmaniyan, K. and Ganesaraja, V. (2012). Nutrient management for sustainable groundnut productivity in India - A review. International Journal of Engineering Science. 11(3): 8138-8153.

Yadav, R.L., Sen, N.L. and Yadav, B.L. (2003). Response of onion to nitrogen and potassium fertilization under semi-arid condition of Rajasthan. Indian Journal of Horticulture. 60: 176-178.

Wang, M., Zheng, Q., Shen, Q. and Guo, S. (2013). The critical role of potassium in plant stress response. International Journal of Molecular Sciences. 14(4): 7370-7390.

Zörb, C., Senbayram, M. and Peiter, E. (2014). Potassium in agriculture - Status and perspectives. Journal of Plant Physiology. 171: 656-669. 